\title{
The relationship between math anxiety, student engagement in mathematics and responsibilities towards learning among middle school students
}

\author{
Dilek Çağırgan, İstanbul University-Cerrahpaşa, Turkey, cagirgan@istanbul.edu.tr, ORCID: 0000-0002- \\ 8212-4968 \\ Illker Soytürk, Kent State University, USA, i.soyturk@gmail.com, ORCID: 0000-0001-7968-6655
}

\begin{abstract}
Learning responsibility is an important concept in students' school success because responsible learners perceive responsibility for learning as a tool for achieving school success and individual career goals. This study aimed to investigate if math anxiety and students' engagement in mathematics predict students' responsibilities toward learning above and beyond that accounted for by gender, grade level, loving math, loving math teacher, owning room, parents' involvement in students' studies using Hierarchical Regression Analysis. Data were collected from 568 middle school students. The results showed that students' social, emotional, and cognitive engagement in mathematics were found to be positively associated with students' responsibility towards learning whereas math anxiety was significant and negative predictor of the students' responsibility towards learning. The finding suggests that student's responsibility towards learning is associated with math-related activities and behaviors. Future studies may investigate a cause-effect relationship using same sample and other classes such as science, linguistic, history.
\end{abstract}

Keywords: Learning Responsibility, math anxiety, engagement in mathematics, middle school

$$
\text { Received: } 17.05 .2020
$$$$
\text { Accepted: 08.08.2020 }
$$

Published: 01.12.2020

\section{INTRODUCTION}

In today's information age, the education of qualified individuals who reach to information instead of ready-to-use individuals comes to the forefront in education. Raising individuals who question, research and produce in the rapidly changing and developing world with technological developments becomes an important aspect of education. Well-developed educational programs help to configure the educational environment; therefore, a qualified education program in today's information and technology age is expected to develop reasoning and problem-solving skills of individuals. In this context, mathematical knowledge and skills play an important role as an interdisciplinary relationship between individuals.

Development of science, philosophy and mathematics in world history is older and more important than the history of wars and leaders. The reason for this is that mathematics constitutes the most important dimension of all kinds of human activities from the beginning up to today (Mankiewicz, 2002). Mathematics provides important support such as thinking, linking between events, reasoning, making predictions and problem solving, which enable individuals to survive in a more complex life they currently live (Baykul, 1998). Without sufficient mathematical culture, it is not possible to contemplate and follow the developments in any science adequately (Işık, \& Bekdemir, 1998). As Olkun and Toluk (2007) stated, today, almost all kinds of professions require more or less mathematics and especially mathematical thinking. Therefore, teaching mathematics and acquiring mathematical skills are the most powerful tools to be learned for order and organization of the developing world (Betz, 1978).

Mathematics constitutes an important key point in the future stage of education besides individuals' current education (Şentürk, 2010). Although the importance and necessity of mathematics is indisputable; it often emerges as a lesson that students do not like, feared, have difficulty in learning and fail (Kutluca, Alpay \& Kutluca, 2015). The most important factors in influencing mathematics achievement were students' ability, attitude, perception, belief, motivation, self-regulation, self-concept, self-confidence, self-efficacy socio-economic variables, 
parental and peer influence, and school-related variables (Nicolaidou \& Philippou, 2003; Singh, Granville \& Dika, 2002). One of these factors comes to the forefront as commitment concept, which is closely related to student achievement in studies (Mazman Akar, Birgin, Goksu, Uzun, Gumus, \& Peker, 2017).

Student engagement in educational settings, in general, is defined as engagement and involvement in the learning process, sense of belonging to school, as well as participation in the school environment and achieving results associated with expected academic, social and affective learning outcomes (Christenson, Reschly, Appleton, Berman-Young, Spanjers, \& Varro, 2008). Student engagement was categorized by Rimm-Kauffman (2010) into three categories: social, cognitive and affective (Mazman Akar et al., 2017). Studies found that increasing the students' engagement in mathematics course will also result in increase their success in mathematics course and revealing the commitment will provide motivation in the process (Leis, Schmidt \&Rimm-Kaufman, 2015; Reeve, Jang, Carell, Jeon \& Barch, 2004). Disconnection of interest and interest in mathematics can lead to serious problems and difficulties for students in the learning process, such as poor mathematics achievement (Mazman Akar et al., 2017). Therefore, researching the concept of student engagement in mathematics and its structures becomes an important topic in mathematics education.

Many emotional factors negatively affect mathematics achievement and math anxiety is one of the most well-known and researched factors (Bindak, 2005; Gülleroğlu, 2017; Ramirez et al., 2016). The most well-known accepted definition in the literature defines as individuals experiencing discomfort from activities or events that require mathematical performance (Wood, 1988) or to feel tension, helplessness, and spiritual disarray when using numbers and shapes (Richardson \& Suinn, 1972).Researches show that many children' mathematics anxiety begins in their early life. Even though students first experienced mathematics anxiety in fourth grade (Tankersley, 1993), and only around 16 percent of students experienced in their third and fourth grade, the proportion of students who experienced mathematic-related stress in their first year at college increased 27 percent according to Jackson and Leffingwell (1999). Moreover, Jackson and Leffingwell (1999) added that "only 7 percent had only positive experiences with mathematics from kindergarten through college" (p. 583). At that point, math anxiety of people increases from their early school lives through their college years. Especially in cases of extreme math anxiety, students' achievement levels and long-term attitudes towards mathematics can be negatively affected. However, math anxiety is not entirely negative. Low-level anxiety students have a motivating function (Baloğlu, 2001).

Researches show that students who love mathematics have less math anxiety than students who do not like it (Bozkurt, 2012; Sırmacl, 2007; Şentürk, 2010; Yüksel-Şahin, 2008) and students with low math anxiety have a positive attitude towards mathematics (Baloğlu, 2001; Bozkurt, 2012; Şentürk, 2010; Wigfield \& Meece, 1988;). On the other hand, a study conducted by Çağırgan, Poyraz, and Batdal Karaduman (2012) found a positive relationship between the attitude developed against mathematics and the daily mathematics study time. Students who love mathematics spend more time with mathematics, those who spend more time with mathematics have higher mathematics performance, and mathematics anxiety of students with higher mathematics achievement is significantly lower (Bozkurt, 2012; Durmaz \& Akkuș, 2016; Mert \& Baş, 2019; Öztop \& Toptaş, 2019). Moreover, students who love mathematics and have low anxiety are interested in mathematics and they spend more and more qualified time with mathematics. This situation can be considered as an indicator that students have responsibility for learning.

Learning responsibility is expressed as the student taking the necessary decisions in order to obtain qualified learning results, managing his / her own learning process, monitoring and evaluating the learning results and taking the necessary importance (Eriști, 2017; Roper, 2007). Learning responsibility is one type of responsibilities emphasized in the literature (Barr \& Tagg, 1995; Carnell, 2005; Cook-Sather \& Luz, 2015; Hughes, 2001; Kaya \& Doğan, 2014; Young, 2005). Learning responsibility has a special importance in terms of being a key structure in students' success in school and other responsibilities in academic life (Yakar \& Saracaloğlu, 2017; Yeşil, 2013) because responsible learners see responsibility for learning as a tool for school success, 
long-term individual career goals, organizing, taking action, and can change their behavior when necessary for their success (Barr \& Tagg, 1995) and found a significant and positive relationship between the level of fulfillment of learning responsibilities and students' academic achievement (Gynnilda, Holstad, \& Myrhaug, 2008; Lan, 1996).

In the light of aforementioned, the purpose of this study was to examine if math anxiety and students' engagement in mathematics predict students' responsibilities toward learning above and beyond other set of independent variables. In this purpose, some demographics (e.g., gender, grade level), emotional attachment toward mathematics (i.e., loving math and loving math teacher), and home related variables(i.e., owning room and parents' involvement in students' studies) were chosen to control the effect of other variables in the models. Following research question was addressed in this study:

Does students' engagement in mathematics and math anxiety predict students' responsibilities toward learning after controlling for demographic (i.e., gender, grade level), emotional attachment toward mathematics (i.e., loving math and loving math teacher), and home related variables (i.e., owning room and parents' involvement in students' studies)?

\section{METHODS}

\section{Participants}

Participants of this study included students who are in middle schools $(N=568)$. Data were collected in three different middle schools in Istanbul and school administrators were asked to collaborate with the data collection process. During data collection process, students' questions related to present study were answered. Table 1 displays descriptive statistics for the variables used in this study.

Table 1. Descriptive statistics of participants $(N=568)$

\begin{tabular}{|c|c|c|}
\hline Variables & $M(S D)$ or $N(\%)^{*}$ & Coding \\
\hline \multicolumn{3}{|l|}{ Gender } \\
\hline Male & $278(48.9)$ & 0 \\
\hline Female & $290(51.1)$ & 1 \\
\hline \multicolumn{3}{|l|}{ Grade Level } \\
\hline Fifth Grade & $138(24.3)$ & Fifth \\
\hline Sixth Grade & $148(26.1)$ & Grade is \\
\hline Seventh Grade & $144(25.4)$ & the \\
\hline Eighth Grade & $138(24.3)$ & $\begin{array}{l}\text { reference } \\
\text { group }\end{array}$ \\
\hline \multicolumn{3}{|l|}{ Having Own Room } \\
\hline Yes & $422(74.3)$ & 1 \\
\hline No & $146(25.7)$ & 0 \\
\hline \multicolumn{3}{|l|}{ Parent Intervention } \\
\hline Yes & $278(48.8)$ & 1 \\
\hline No & $290(51.1)$ & 0 \\
\hline \multicolumn{3}{|l|}{ Love Mathematics } \\
\hline Yes & $473(487.3)$ & 1 \\
\hline No & $95(16.7)$ & 0 \\
\hline \multicolumn{3}{|l|}{ Love Math teacher } \\
\hline Yes & $496(87.3)$ & 1 \\
\hline No & $72(12.7)$ & 0 \\
\hline
\end{tabular}

There were 278 (48.9\%) male students and 290 female students (51.1\%). The dataset was evenly distributed by class. There were 138 fifth graders (24.3\%), 148 sixth graders $(26.1 \%), 144$ seventh graders $(25.4 \%)$, and 138 eight graders $(24.3 \%)$. Also, $74.3 \%$ of the students $(\mathrm{N}=422)$ specified that they have their own room while 146 students $(25.7 \%)$ stated that they do not have 
their own study room in their home. Out of 568 students, 278 students (48.9\%) self-reported that their parents intervened them to complete their schoolwork, whereas $51.1 \%$ of the students reported that they start studying before their parents intervened them. Students were also asked whether or not they like mathematics and their mathematics teachers. The majority of the students $(n=473)$ reported that they love mathematics. Similarly, those who love their mathematics teachers comprised around $87 \%$ of the data set $(n=496)$.

\section{Measures}

In order to complete the survey, students were given 40 minutes class period. The survey included two main parts. First, students completed the demographic information part. In the second part, students completed following three Likert-type scales.

\section{Scale of Responsibility towards Learning}

Students' responsibilities towards learning was measured using Scale of Responsibility towards Learning developed by Yakar and Saracoglu (2017).The Responsibility towards Learning Scale consists of 35 items using 5 point-Likert scale ranging from "Not Suitable for me" to "Completely suitable for me". Yakar and Saracoglu (2017) included a total of 335 students in middle school from fifth through eighth grade. Higher scores in the scale indicates more responsibility towards learning. The scale has a unidimensional factor structure and the Coefficient Alpha was reported at 0.94. The Coefficient Alpha in the present sample was 0.946 .

\section{Student Engagement in Mathematics Scale}

Student Engagement in Mathematics Scale was developed by Mazman-Akar and her colleagues (2017) to measure children's engagement in mathematics after a math class. The Student Engagement in Mathematics Scale consists of 13 items using 4 point-Likert scale ranging from "No, not all true to" to "Yes, very true". Mazman-Akar et al. (2017) included 602 middle school students. Higher scores in the scale indicate more student engagement in mathematics. The scale consists of three sub dimensions including social, emotional, and cognitive engagement with mathematics and the Coefficient Alpha was reported at 0.872. The Coefficient Alpha in the present sample was 0.888 .

\section{Math Anxiety Scale}

The Math Anxiety Scale (MAS; Bindak, 2005) was used to measure middle school students' math anxiety level. In the initial measure development study, the data were collected from 122 seventh graders. The final MAS has 10 items including one reversely coded item on a 5- point Likert scale. The response structure includes "Never" to "Always", with a potential score range of 10 to 50. Higher scores indicate more math anxiety. Coefficient (Cronbach's) $\alpha$ was .84 in the initial study. The Coefficient Alpha in the present sample was 0.865.

\section{Data Analysis}

All analyses in this study was performed using IBM SPSS Version 21 (IBM Corp., 2012). Descriptive statistics for both independent variables and dependent variables are provided in Table 2. Categorical independent variables were dummy coded prior to the analysis. In order to test the research questions, the data were analyzed using hierarchical multiple regression analysis with the variables in the five-block model which were entered into the analysis in order.

Hierarchical Multiple Regression allows to see the changes in the variance of dependent variable by adding a set of predictors while controlling for the effects of the predictors that are previously entered into the model (Keith, 2014). In this study, starting from students' demographic information (e.g., gender, grade level), a total of 10 predictors into the model were added into five block in a sequential order and contribution of the each set of predictors were analyzed by checking the changes in the coefficient of determination $\left(\Delta \mathrm{R}^{2}\right)$. Existing evidence of the association between variables used in this study helped to build the following model was proposed and evaluated in this study: 
Responsibilities $=$ gender, grade level $($ Block 1$)+$

Toward owning room, parents' involvement in students' studies (Block 2) +

learning loving math, loving math teacher (Block 3) +

math anxiety (Block 4) +

social, emotional, and cognitive engagement in mathematics (Block 5).

\section{RESULTS}

\section{Preliminary analyses Assumption checking and descriptive statistics}

Prior to the data analysis process, assumptions for the hierarchical multiple regression were examined. The linearity assumption, which is accepted as the most important assumption in multiple regression (Dimitrov, 2013), was tested by examining the scatterplot of each independent continuous variable and dependent variable. The results suggested that the assumption of linearity was upheld. Also, the assumptions of normality and homoscedasticity were also met using residual scatterplots. The Durbin-West test was used to test the assumption of independence of errors and the results revealed that the assumption was met. Last, there was no multicollinearity issue based on the Variance Inflation Factor (VIF) and Tolerance values. Table 2 shows descriptive statistics regarding dependent variable and independent continuous variables used in this study.

Table 2. Descriptive Statistics for the dependent variable and continuous independent variables (N $=568$ )

\begin{tabular}{lccccc}
\hline Variables & $\mathbf{1}$ & $\mathbf{2}$ & $\mathbf{3}$ & $\mathbf{4}$ & $\mathbf{5}$ \\
\hline 1. Responsibility & - & $-.352^{*}$ & $.491^{*}$ & $.542^{*}$ & $.585^{*}$ \\
2. MathAnxiety & & - & $-.314^{*}$ & $-.397^{*}$ & $-.275^{*}$ \\
3. SocialEng & & & - & $.508^{*}$ & $.577^{*}$ \\
4. EmotionalEng & & & - & $.697^{*}$ \\
5. CognitiveEng & & & & & - \\
M & 135.84 & 27.84 & 10.87 & 14.03 & 11.94 \\
SD & 24.42 & 7.11 & 3.25 & 4.16 & 3.04 \\
\hline
\end{tabular}

Note. ${ }^{*} p<.01$, Responsibility = Responsibility towards Learning, MathAnxiety = Math Anxiety, SocialEng = Social Engagement in Mathematics, Emotional Engagement in Mathematics = EmotionalEng, CognitiveEng = Cognitive Engagement in Mathematics

As seen in Table 2, the results indicated that there was a significant, negative correlation between students' responsibilities for learning and math anxiety $(p<.001)$. Similarly, there was a significant, negative correlation between each of subscales of students' engagements in mathematics (i.e., social, emotional, and cognitive) and students' math anxiety level $(\mathrm{p}<.001)$. However, students' responsibilities for learning was significantly and positively correlated with each of subscales of students' engagements in mathematics $(p<.001)$.

\section{Results from Hierarchical Multiple Linear Regression}

Followed by checking assumptions and conducting some descriptive statistics analysis, Hierarchical Multiple Linear Regression analysis was conducted. Table 3 shows the model summary results for each block and corresponding regression coefficients within blocks. The results suggested that each block significantly added to the prediction of the criterion variable (i.e., students' responsibilities for learning). Together, final model (i.e., with all 10 predictors) accounted for approximately $48 \%$ of the variance in students' responsibilities towards learning scores. The variables in the first block (i.e., gender and grade level) were significant predictors of students' responsibilities towards learning. In more detail, gender was a statistically significant predictor of the students' responsibilities towards learning $(p=.026)$ and female students' responsibilities towards learning was around 7.283 points higher than male students $(\beta=.149$; 
$B=7.283, S E=1.958$ ). Those who were in fifth grade had 8.401 points higher responsibilities towards learning than sixth graders, 17.244 points higher responsibilities towards learning than seventh graders, and 13.782 points higher responsibilities towards learning than eight graders.

Followed by the Block 1, the analysis was repeated by adding two new predictors (having own room at home and parent intervention) in Block 2 and these two predictors were assessed along with variables from the Block 1 . The model in Block 2 was statistically significant. Those who have own rooms had 8.364 points higher responsibilities towards learning than those who do not $(B=8.364, S E=2.181)$ after controlling other predictors in the model. On the other hand, those who are intervented by parents had 8.913 points lower responsibilities towards learning than those whose parents did not intervent students $(B=-8.913, S E=1.931)$ after controlling other predictors in the model. Gender and grade levels were still statistically significant predictors on students' responsibilities towards learning in Block 2.

In the third block, two more predictors in addition to predictors in the first two blocks were entered into the model. The model in Block 3 was statistically significant. In detail, students who self-reported that they love mathematics have 15.666 points higher responsibilities towards learning than those who do not love mathematics $(B=15.666, S E=2.863)$ after controlling other predictors in the model. Similarly, students who self-reported that they love their mathematics teachers had 11.966 points higher responsibilities towards learning than those who do not love $(B=11.966, S E=3.157)$ after controlling other predictors in the model. Again, after adding two predictors into Block 3, other predictors in the first two blocks were still statistically significant predictors for responsibilities towards learning.

In Block 4, students' math anxiety scores were added to model and this predictor had a significant contribution for predicting students' responsibilities towards learning. Students' math anxiety level was a statistically and negative predictor $(B=-.696, S E=.129)$ of responsibilities towards learning. In other words, students' responsibilities towards learning decreases by 696 points as a students' math anxiety level increases one unit after holding other variables in the model constant.

In the last block, Block 5, students' three sub dimensions of the students' engagement in mathematics were added into the model. Block 5 continued to add to the over and above the contributions made by the previous block. The results suggested that social engagements in mathematics $(B=1.314, S E=.301)$, emotional engagements in mathematics $(B=.640, S E=.292)$, and cognitive engagements in mathematics $(B=2.205, S E=.378)$ were significant predictors for students' responsibilities towards learning. In other words, students' responsibilities towards learning increases by 1.314 points as students' social engagement in mathematics increases one unit after holding other variables in the model constant. Similarly, students' responsibilities towards learning increases by .640 points as students' emotional engagement in mathematics increases one unit after holding other variables in the model constant. Last, students' responsibilities towards learning increases by 2.205 points as students' cognitive engagement in mathematics increases one unit after holding other variables in the model constant. After adding these three predictors in the last block, all predictors except one variable (i.e., the love of mathematic teachers) in the previous models were still statistically significant predictors for students' responsibilities for learning.

\section{DISCUSSION and CONCLUSIONS}

This study had an exploratory nature and aimed to investigate the relationship between students' engagement in mathematics, math anxiety, and students' responsibilities toward learning after controlling for gender, grade level, loving math, loving math teacher, owning room, parents' involvement in students' studies. First, there was a significant difference between girls and boys in favor of girls. When similar studies were examined (Hughes, 2001; Illeris, 2003; Senemoğlu, 2011; Yeşil, 2013), similar results have been reached. As stated by Yeşil (2013), female students are emotionally more dependent on school and teacher than male students, while male students have different efforts to do outside the school life. It may be due to the fact that there are more places and environments in which different activities will be held for men in social 
life. However, Hughes (2001) found that women are more prone to take emotional and social responsibility than men. This is related to the nature of femininity and the most concrete way manifests itself in the form of dependence on the family. Accordingly, it may be useful to find ways to motivate male students to enhance their responsibility toward learning. In addition, learning activities by ensuring a balanced participation of boys and girls can be organized.

Table 3. Hierarchical Multiple Linear Regression for Predicting Responsibility towards Learning (N $=568)$

\begin{tabular}{|c|c|c|c|c|c|c|c|}
\hline \multirow[t]{2}{*}{ Block } & \multirow[t]{2}{*}{ Predictor } & \multicolumn{6}{|c|}{ Model Summary } \\
\hline & & B & SE & $\beta$ & F Statistics & $\mathbf{R}^{2}$ & $\Delta \mathbf{R}^{2}$ \\
\hline \multirow[t]{5}{*}{1} & & & & & $\begin{array}{c}F(4,563)= \\
14.894^{*}\end{array}$ & .096 & $.096^{*}$ \\
\hline & $\begin{array}{l}\text { Gender } \\
\text { Grade Level }\end{array}$ & 7.283 & 2.25 & $.149^{*}$ & & & \\
\hline & Sixth Grade & -8.041 & 1.96 & $-.145^{* *}$ & & & \\
\hline & Seventh Grade & $\begin{array}{c}- \\
17.244\end{array}$ & 2.76 & $-.307^{*}$ & & & \\
\hline & Eighth Grade & $\begin{array}{c}- \\
13.782\end{array}$ & 2.78 & $-.242^{*}$ & & & \\
\hline \multirow[t]{7}{*}{2} & & & & & $\begin{array}{c}F(6,561)= \\
16.854^{*}\end{array}$ & .153 & $.057^{*}$ \\
\hline & $\begin{array}{l}\text { Gender } \\
\text { Grade Level }\end{array}$ & 5.764 & 2.86 & $.118^{* *}$ & & & \\
\hline & Sixth Grade & -7.376 & 1.92 & $-.133^{* *}$ & & & \\
\hline & Seventh Grade & $\begin{array}{c}- \\
15.593\end{array}$ & 2.68 & $-.278^{*}$ & & & \\
\hline & Eighth Grade & $12 . \overline{-}$ & 2.72 & $-.224^{*}$ & & & \\
\hline & HavingOwnRoom & 8.364 & 1.81 & $.150^{*}$ & & & \\
\hline & ParentIntervention & -8.913 & 1.93 & $-.183^{*}$ & & & \\
\hline \multirow[t]{9}{*}{3} & & & & & $\begin{array}{c}F(8,559)= \\
26.049^{*}\end{array}$ & .272 & $.119 *$ \\
\hline & $\begin{array}{l}\text { Gender } \\
\text { Grade Level }\end{array}$ & 5.796 & 1.78 & $.119 *$ & & & \\
\hline & Sixth Grade & -6.553 & 2.50 & $-.118^{* *}$ & & & \\
\hline & Seventh Grade & 11.438 & 2.56 & $-.204^{*}$ & & & \\
\hline & Eighth Grade & -9.221 & 2.56 & $-.162^{*}$ & & & \\
\hline & Having OwnRoom & 8.421 & 2.03 & $.151^{*}$ & & & \\
\hline & ParentIntervention & -6.959 & 1.81 & $-.143^{*}$ & & & \\
\hline & Love Matematics & 11.996 & 3.16 & $.164^{*}$ & & & \\
\hline & Love Math Teacher & 15.666 & 2.86 & $.240^{*}$ & & & \\
\hline \multirow[t]{8}{*}{4} & & & & & $\begin{array}{c}F(9,558)= \\
27.535^{*}\end{array}$ & .308 & $.036^{*}$ \\
\hline & $\begin{array}{l}\text { Gender } \\
\text { Grade Level }\end{array}$ & 5.598 & 1.74 & $.115^{*}$ & & & \\
\hline & Sixth Grade & -5.772 & 2.44 & $.104^{-}$ & & & \\
\hline & Seventh Grade & -9.088 & 2.54 & $-.162^{*}$ & & & \\
\hline & Eighth Grade & -7.356 & 2.52 & $-.129 * *$ & & & \\
\hline & HavingOwnRoom & 7.176 & 1.99 & $.129^{*}$ & & & \\
\hline & ParentIntervention & -6.160 & 1.77 & $-.126^{*}$ & & & \\
\hline & Love Matematics & 9.769 & 3.11 & $.133^{* *}$ & & & \\
\hline
\end{tabular}




\begin{tabular}{lcccccc} 
Love Math Teacher & 14.460 & 2.80 & $.221^{*}$ & & & \\
MathAnxiety & -.696 & .129 & $-.203^{*}$ & & & \\
& & & & $F(12,555)=$ & .477 & $.169^{*}$ \\
& & & & & \\
Gender & 4.587 & 1.54 & $.094^{* *}$ & & \\
Grade Level & & & & & \\
Sixth Grade & -5.963 & 2.15 & $-.101^{* *}$ & & \\
Seventh Grade & -8.542 & 2.24 & $-.152^{*}$ & & \\
Eighth Grade & -5.915 & 2.66 & $-.104^{* *}$ & \\
HavingOwnRoom & 4.268 & 1.77 & $.076^{* * *}$ & \\
ParentIntervention & -3.564 & 1.56 & - & \\
& & & $.073^{* * *}$ & \\
Love Matematics & 3.795 & 2.78 & .052 & & \\
Love Math Teacher & 7.579 & 2.53 & $.116^{* *}$ & \\
MathAnxiety & -.311 & .119 & $-.090^{* *}$ & \\
SocialEng & 1.314 & .30 & $.175^{*}$ & \\
EmotionalEng & .640 & .29 & $.109^{* * *}$ & \\
CognitiveEng & 2.205 & .38 & $.175^{*}$ & \\
\hline
\end{tabular}

Note. ${ }^{*} p<.001,{ }^{* *} p<.01,{ }^{* * *} p<.05$.

The responsibility of the 5th grade students in the research towards learning was higher than the 6th, 7th and 8th grades. Accordingly, it can be said that in general, as the grade level of the students increases, there is a decrease in the level of learning responsibilities. Yesil (2013) found a similar result that students on the lower grade level had higher learning responsibilities than their peers in the upper-class. Also, Davis and Murrell (1994) stated that the awareness of responsibility in the students is shaped according to their experiences and observations and students were negatively affected by irresponsible behaviors observed in their friends. On the other hand, the anxiety that may be caused by the transition to high school may be caused by the fact that they undertake the responsibilities of the classroom as well as the school learning and that the students do not fulfill their responsibilities related to school learning adequately. This situation can be interpreted as the problem that the school has problems in fulfilling its function in terms of acquiring the learning responsibilities to the students or it cannot be fulfilled in the desired direction because it is expected from educational institutions to contribute to the students to be more sensitive in fulfilling their learning responsibilities (Yeşil, 2013). Schools are the institutions that aim to provide and develop students' sense of responsibility (Macready, 2009; Romi, Lewis \& Katz, 2005; Töremen, 2011; Young, 2005). In this context, the school should support and carry out studies on learning responsibility in a way that meets the needs of students in each classroom. Also, as the grade level progresses, supportive guidance services can be used to ensure that there is no decline in students' learning responsibilities.

Another finding of the study is that students who are intervened by their parents have lower responsibility for learning than those who are not stimulated. A study conducted by Erozkan (2012) with high school students showed that there were relationships between the attitudes of parents and children's anxiety sensitivities and that children were affected negatively by the repressive attitudes and behaviors of the parents. As it is known, the expectations of the parents, teachers and peer groups shape the individual's sense of responsibility or consciousness in parallel with the developmental periods of the individual (Senemoğlu, 2009; Yeșil, 2003; Yeşil, 2013). Accordingly, parents should monitor students' learning activities, give the message that they are with them when they need them, but should not interfere too much and prevent them from taking initiative on their own responsibilities.

Those who have the study room have higher responsibility for learning. The studies show that family, self and general satisfaction of students who have their own room at home are more than those who do not have room (Arpacı \& Ersoy, 2003; Çivitci, 2009). The better environments in students' home can be considered to have a positive impact on the responsibility for learning. 
Therefore, it is advisable to provide at least an environment where students who are unlikely to have the room.

Finding in this research suggested that those who love mathematics and mathematics teachers have higher responsibility for learning and those with math anxiety have lower responsibility for learning. Also, as students' dependence on social, cognitive and emotional mathematics increases, their responsibility towards learning increases. When the findings were evaluated in general, it was found that there was a significant difference between the likes/dislikes of mathematics and math anxiety by the researches (Şentürk, 2010; Yüksel-Şahin, 2008). In addition, students who do not like mathematics teachers have significantly higher levels of math anxiety than the students who love mathematics, and loving teacher affects the attitude towards the lesson in primary school students (Bozkurt, 2012; Yüksel-Şahin, 2008). It is important that behaviors related to learning responsibility are not limited to efforts and actions within the school or classroom (Brooks, \& Brooks, 2006). Therefore, it can be said that the students who love the mathematics lesson and their teacher have a positive sense of responsibility towards this lesson and their anxiety is low. In this context, it can be clearly seen that learning responsibility and anxiety in mathematics lesson are related to loving the teacher as well as loving the lesson. Accordingly, it can be suggested to conduct studies to inform teachers that math anxiety and responsibility towards learning lesson are related to students' love of the lesson and the teacher.

Another finding of this study was the negative relationship between math anxiety and students' responsibility toward learning. As aforementioned, students who spent time for mathrelated activities have more motivation to be successful in mathematics (Bozkurt, 2012). Gaining this interaction with mathematics would lead students having more positive attitude toward mathematics and help to decrease the level of math anxiety among learners. National Scientific Council on the Developing Child (2010) highlights that having afraid and anxiety in events impacts the development of the brain, where areas in emotions and learning. In sum, this finding may be exploratory of the negative relationship between math anxiety and students' responsibility toward learning. Therefore, students who suffering anxiety in math could be given special and achievable responsibilities that the students can be self-confident in their learning process.

Last, students' emotional, social, and cognitive engagement in mathematics were found to be positively related with students learning responsibilities. As Hannula and his colleagues (2016) stated engaging with mathematics impacts one's attitude, beliefs, and motivation. Also, some other researchers revealed that best learning occurs when the students are engaged, and this engagement end it up with higher performance in mathematics (Attard, 2012; Lim, Tan, \& Lin, 2012;). Kong, Wong, \& Lam, (2003) stated that interest and engagement in mathematics play a critical role for the involvement of students in mathematics learning and problem solving. Vega and Priesto (2012; cited in Zantua \& Lapinid, 2018) highlights that adolescents choose various learning activities and they shows their eagerness for taking responsibility for their learning.

This study has some potential limitations in nature. The first limitation is that the sample included students in three middles schools in Istanbul. This makes hard to generalize the results to the students in middle schools in Turkey beyond the sample the sample was collected. This limitation lowers the external validity of this research. Therefore, future studies should collect data in more diverse and multiple research site. The second limitation concerns the data collection steps using paper-pencil format using self-report questionnaire. Although the students were asked to provide their opinion using previously developed and validated scales, this study relies on the data provided by students. The reason for this second limitation is students may have responded more favorably the survey even though they were assured the confidentiality of the data. In addition, since the nature of this current study was a correlational design, the interpretation of the results should be done with a causation. The relationship between variables does not imply cause and effect relationship; therefore, the readers should not establish the causal relationship from the findings of this study. Future studies can design some experimental studies to test the cause-effect relationship using same sample. Last, this study focused on the variables that are related to mathematics. The findings in this study should not be generalized to 
the other classes such as science, linguistic, history. Future studies should focus on other classes and related variables in the relationship with students' responsibilities towards learning.

\section{REFERENCES}

Arpacı, F. \& Ersoy, A.F. (2003). Orta öğretim öğrencilerinin konut koşulları ve konutun gencin gelişimi üzerindeki etkilerinin incelenmesi. Gazi Üniversitesi Gazi Eğitim Fakültesi Dergisi, 23(3), 1-17.

Attard, C. (2012). The influence of pedagogy on student engagement with mathematics during the middle years of schooling. Transforming School Mathematics in the 21st Century, 140-157.

Baloğlu, M. (2001). Matematik korkusunu yenmek. Kuram ve Uygulamada Eğitim Bilimleri Dergisi, 1(1), 5976.

Barr, B.R. \& Tagg, J. (1995). From teaching to learning: A new paradigm for undergraduate education. Change, 27(6), 697-710.

Baykul, Y. (1998). İlköğretim birinci kademede matematik öğretimi. Ankara: MEB Yayınları.

Betz, N. E. (1978). Prevalence, distribution, and correlates of math anxiety in college students. Journal of Counseling Psychology, 25(5), 441.

Bindak, R. (2005). İlkögretim Ögrencileri için Matematik Kaygı Ölçeği. Fırat Üniversitesi Fen ve Mühendislik Bilimleri Dergisi, 17 (2), 442-448.

Bozkurt, S. (2012). Illköğretim ikinci kademe öğrencilerinde sınav kaygısı, matematik kaygısı, genel başarı ve matematik başarısı arasındaki iliş̧kilerin incelenmesi. İstanbul Üniversitesi, Sosyal Bilimler Enstitüsü: İstanbul.

Brooks, J.G. \& Brooks, M.G. (2006). In search of understanding: The case for constructivist classrooms. (Revised Ed). Alexandria, Va: Association for Supervision and Curriculum Development.

Carnell, E. (2005). Understanding and enriching young people's learning: issues, complexities and challenges. Improving Schools, 8(3), 269-284.

Cook-Sather, A., \& Luz, A. (2015). Greater engagement in and responsibility for learning: What happens when students cross the threshold of student-faculty partnership, Higher Education Research ve Development, 34(6), 1097-1109.

Christenson, S. L., Reschly, A. L., Appleton, J. J., Berman-Young, S., Spanjers, D. M., \& Varro, P. (2008). Best practices in fostering student engagement. In A. Thomas \& J. Grimes (Eds.), Best practices in school psychology (5th ed., pp. 1099-1119). Bethesda, MD: National Association of School Psychologists.

Çağırgan Gülten D., Poyraz C., \& Batdal Karaduman G. (2012). The relationship between elementary students attitudes towards mathematics and studying to mathematics. International Journal on New Trends in Education and Their Implications, 3(1), 20-31.

Çivitci, A. (2009). İlköğretim öğrencilerinde yaşam doyumu: Bazı kişisel ve ailesel özelliklerin rolü. Uludă̆ Üniversitesi Eğitim Fakültesi Dergisi, 22(1), 29-52.

Davis, T.M. \& Murrell, P.H. (1994). Turning teaching into learning: The role of student responsibility in the collegiate experience. ASHE-ERIC Higher Education Report No: 8. ERIC Identifier: ED372702.

Dimitrov, D. M. (2013). Quantitative research in education: Intermediate \& advanced methods. Oceanside, NY: Whittier Publications.

Durmaz, M. \& Akkuș, R. (2016). Mathematics anxiety, motivation and the basic psychological needs from the perspective of self-determination theory. Education and Science, 41(183), 111-127.

Erişti, B. (2017). Öğrenme sorumluluğu ölçeğinin geliştirilmesi. Necatibey Eğitim Fakültesi Elektronik Fen ve Matematik Ĕ̈itimi Dergisi, 11(1), 481-503.

Erozkan, A. (2012). Examination of relationship between anxiety sensitivity and parenting styles in adolescents. Kuram ve Uygulamada Eğitim Bilimleri-Educational Sciences: Theory \& Practice, 12(1), 52-57.

Gülleroğlu, H. D. (2017). An investigation of measurement invariance by gender for the Turkish students' affective characteristics who took the PISA 2012 math test. Gazi University Journal of Gazi Educational Faculty (GUJGEF) 37(1), 151-175.

Gynnilda, V., Anders, H. \& Myrhaug, D. (2008). Identifying and promoting self-regulated learning in higher education: Roles and responsibilities of student tutors. Mentoring \& Tutoring: Partnership in Learning, 16(2), 147-161.

Hannula, M. S., Di Martino, P., Pantziara, M., Zhang, Q., Morselli, F., Heyd-Metzuyanim, E., ... \& Goldin, G. A. (2016). Attitudes, beliefs, motivation, and identity in mathematics education. In Attitudes, Beliefs, Motivation and Identity in Mathematics Education (pp. 1-35). Springer, Cham.

Hughes, C. (2001). Developing conceptual literacy in lifelong learning research: a case of responsibility? British Educational Research Journal, 27(5), 601-614. 
Jackson, C. D., \& Leffingwell, R. J. (1999). The role of instructors in creating math anxiety in students from kindergarten through college. The Mathematics Teacher, 92(7), 583-586.

Illeris K. (2003). Learning, identity and self-orientation in youth. Young, 11(4), 357-376.

Işık, A., \& Bekdemir, M. (1998). Matematiğin doğası ve eğitimdeki yeri. Çağdaş Eğitim Dergisi, 245(9), 19 22.

Kaya, M., \& Doğan, U. (2014). Öğrenci sorumluluk: Ölçek geliştirme, güvenirlik ve geçerlik çalışması. Journal of European Education, 4(1), 11-18.

Keith, T. Z. (2014). Multiple regression and beyond: An introduction to multiple regression and structural equation modeling. Routledge.

Kong, Q. P., Wong, N. Y., \& Lam, C. C. (2003). Student engagement in mathematics: Development of instrument and validation of construct. Mathematics Education Research Journal, 15(1), 4-21.

Kutluca, T., Alpay, F. N., \& Kutluca, S. (2015). 8. sınıf öğrencilerinin matematik kaygı düzeylerine etki eden faktörlerin incelenmesi. Dicle Üniversitesi Ziya Gökalp Eğitim Fakültesi Dergisi, 25, 202-214.

Lan, W.Y. (1996). The effects of self-monitoring on students' course performance, use of learning strategies, attitude, self-judgment ability, and knowledge representation. Journal of Experimental Education, 64(2), 101-116.

Leis, M., Schmidt, K. M., \& Rimm-Kaufman, S. E. (2015). Using the partial credit model to evaluate the student engagement in mathematics scale. Journal of Applied Measurement, 16(3), 251-267.

Lim, A., Tan, J. \& Lin, S.W. (2012). The Use of Meaningful Tasks in Teaching Fractions to Enhance Students' Engagement. In A. L. White, \& U.H. Cheah (Eds.), Transforming School Mathematics in Education in the 21st Century. Penang, Malaysia: Publication Unit SEAMEO RECSAM pp. 88-97

Macready, T. (2009). Learning social responsibility in schools: A restorative practice. Educational Psychology in Practice, 25(3), 211-220.

Mankiewicz, R. (2002). Matematiğin tarihi. Çev. Gökçen Ezber. İstanbul: Güncel Yayıncllık.

Mazman Akar, S. G., Birgin, O., Göksu, B., Uzun, K., Gümüș, B., \& Peker, E. S. (2017). Matematik dersine bağlılık ölçeği'nin Türkçe'ye uyarlama çalışması. Turkish Journal of Computer and Mathematics Education, 8(1), 28-51.

Mert, M.,\& Baș, F. (2019). The anxiety and metacognitive awareness levels of secondary school students towards mathematics and the effect of related variables on their mathematics achievements. Turkish Journal of Computer and Mathematics Education (TURCOMAT), 10(3), 732756.

National Scientific Council on the Developing Child. (2010). Persistent Fear and Anxiety Can Affect Young Children's Learning and Development. Harvard University, Center on the Developing Child.

Nicolaidou, M., \& Philippou, G. (2003). Attitudes towards mathematics, self-efficacy and achievement in problem solving. European Research in Mathematics Education III. Pisa: University of Pisa, 1-11.

Olkun, S., \& Toluk-Uçar, Z. (2007). İlköğretimde Etkinlik Temelli Matematik Öğretimi. Maya Akademi, Ankara.

Öztop, F.,\& Toptaş, V. (2019). An evaluation regarding the level of mathematics anxiety of the parents of primary school students. Elementary Education Online, 18(3), 1043-1068.

Ramirez, G., Chang, H., Maloney, E. A., Levine, S. C., \& Beilock, S. L. (2016). On the relationship between math anxiety and math achievement in early elementary school: The role of problem solving strategies. Journal of Experimental Child Psychology, 141, 83-100.

Reeve, J., Jang, H., Carrell, D., Jeon, S., \& Barch, J. (2004). Enhancing students' engagement by increasing teachers' autonomy support. Motivation and Emotion, 28(2), 147-169.

Richardson, F. C., \& Suinn, R. M. (1972). The mathematics anxiety rating scale: psychometric data. Journal of counseling Psychology, 19(6), 551.

Rimm-Kaufman, S. E. (2010). Student engagement in mathematics scale (SEMS). Unpublished measure, University of Virginia, Charlottesville, VA.

Romi, S., Lewis, R., \& Katz, Y. J. (2009). Student responsibility and classroom discipline in Australia, China, and Israel. Compare: A Journal of Comparative and International Education, 39(4), 439-452.

Roper, A.R. (2007). How students develop online learning skills. Educause Quarterly, 30(1), 62-64.

Senemoğlu, N. (2009). Gelişim, öğrenme ve öğretim. (14. baskı). Ankara: PegemA Yayınevi.

Singh, K., Granville, M., \& Dika, S. (2002). Mathematics and science achievement: Effects of motivation, interest, and academic engagement. The Journal of Educational Research, 95(6), 323-332.

Sirmacl, N. (2007). A study on the investigation of the university students' anxiety and attitudes toward mathematics: Erzurum Sample. Education and Science, 32(145), 53-70.

Şentürk, B. (2010). İlköğretim beşinci sınıf öğrencilerinin genel başarıları, matematik başarıları, matematik dersine yönelik tutumları ve matematik kaygıları arasındaki ilişki. Yüksek Lisans Tezi, Afyon Kocatepe Üniversitesi, Sosyal Bilimler Enstitüsü, Afyon.

Tankersley, K. (1993). Teaching math their way. Educational Leadership, 50, 12-13. 
Töremen, F. (2011). The responsibility education of teacher candidates. Kuram ve Uygulamada Eğitim Bilimleri-Educational Sciences: Theory \& Practice, 11(1), 273-277.

Wigfield, A., \& Meece, J. L. (1988). Math anxiety in elementary and secondary school students. Journal of Educational Psychology, 80(2), 210-216.

Wood, E. F. (1988). Math anxiety and elementary teachers: What does research tell us? For the Learning of Mathematics, 8(1),8-13.

Yakar, A. \& Saracaloğlu, A. (2017). Öğrenmeye yönelik sorumluluk ölçeği. Mehmet Akif Ersoy Üniversitesi Eğitim Fakültesi Dergisi, 42, 27-49.

Yeşil, R. (2003). Sorumluluk bilincinin gelişmesine okul ve ailenin etkisi. Eğitim Araştırmaları Dergisi, 9 , 175-183.

Yeșil, R. (2013). Ortaöğretim öğrencilerinin okul öğrenmelerindeki öğrenme sorumluluklarını yerine getirme düzeyleri. International Journal of Human Sciences, 10(1), 1214-1237.

Young, M.R. (2005). The motivational effects of the classroom environment in facilitating self-regulated learning. Journal of Marketing Education, 27(1), 25-40.

Yüksel-Şahin, F. (2008). Mathematics anxiety among 4th and 5th grade Turkish elementary school students. International Electronic Journal of Mathematics Education, 3(3), 179-192.

Zantua, J. A. V., \& Lapinid, M. R. C. (June, 2018). Utilizing Writing Boards in Interactive Mathematics Classes. Paper presented at the DLSU Research Congress 2018 De La Salle University, Manila, Philippines. 